\title{
ANALISIS MUTU PEMBELAJARAN PRAKTIK LABORATORIUM SEBAGAI UPAYA PENINGKATAN MUTU PRAKTIK ASUHAN KEBIDANAN DI PROGRAM STUDI D.III KEBIDANAN TANJUNGKARANG
}

\author{
Sudarmi \\ Jurusan Kebidanan Poltekkes Tanjungkarang \\ Email: sudarmi_65@yahoo.com
}

\begin{abstract}
Abstrack: Analysis Quality Learning of Laboratory Practice as Improvement Quality Practice Midwifery Efforts in Studies DIII Midwifery Tanjungkarang. To produce a professional midwife and have the appropriate competence standards, requiring the management of quality education. Efforts to achieve quality education, in teaching and learning in theory and also practice was need improving quality of learning. This study describes the quality of 1 earning laboratory practice consists of planning, implementing, evaluating and improving the quality of learning. This type of research is descriptive qualitative data gathering through interviews, documentation and observation. The results showed that the quality of teaching laboratory practice in obstetrics D-III Tanjungkarang not in accordance with the standards, most students are not satisfied to get service learning laboratory practice midwifery given by lecturers and laboratory workers. evidenced by the many complaints from students. In need of measures to improve the quality of learning laboratory practice midwifery by applying the concept of PDCA (Plan-DoChek-Act), and to the development dimension of the quality of teaching laboratory practices, the quality of service, namely improvement: reliability (reliability), responsiveness, assurance, empathy and tangible.
\end{abstract}

Keywords: Learning laboratory practice, quality improvement practices

\begin{abstract}
Abstrak: Analisis Mutu Pembelajaran Praktik Laboratorium sebagai Upaya Peningkatan Mutu Praktik Asuhan Kebidanan di Program Studi DIII Kebidanan. Untuk menghasilkan tenaga bidan yang profesional dan mempunyai kompetensi sesuai standar, membutuhkan pengelolaan pendidikan yang berkualitas. Upaya mencapai kualitas pendidikan, dalam proses belajar mengajar secara teori maupun praktik diperlukan usaha peningkatan mutu pembelajaran. Penelitian ini mendeskripsikan mutu pembelajaran praktik laboratorium yang terdiri dari perencanaan, implementasi, evaluasi dan upaya peningkatan mutu pembelajaran. Jenis penelitian ini adalah deskriptif kualitatif dengan pengumpulan data melalui wawancara, dokumentasi dan pengamatan. Hasil penelitian menunjukkan bahwa mutu pembelajaran praktik laboratorium di prodi DIII kebidanan tanjungkarang belum sesuai dengan standar, sebagian besar mahasiswa kurang puas mendapatkan pelayanan pembelajaran praktik laboratorium kebidanan yang diberikan oleh dosen dan petugas laboratorium. terbukti dengan banyaknya keluhan yang dirasakan mahasiswa. Diperlukan langkah-langkah untuk meningkatkan mutu pembelajaran praktik laboratorium kebidanan dengan menerapkan Konsep PDCA (Plan-Do-Chek-Act), dan untuk pengembangan dimensi mutu pembelajaran praktik laboratorium, dalam kualitas pelayanan yaitu dengan peningkatan: kehandalan (reliability), daya tanggap (respon-siveness), kepastian (assurance), empati (emphaty) dan berwujud (tangible).
\end{abstract}

Kata kunci: Pembelajaran praktik laboratorium, peningkatan mutu praktik

Bidan sebagai tenaga kesehatan yang merupakan ujung tombak pemberi pelayanan kesehatan pada masyarakat, dituntut untuk dapat memberikan pelayanan yang prima dan berkualitas sesuai standar yang telah ditetapkan. Peningkatan kualitas tenaga bidan diperlukan untuk dapat menurunkan Angka Kematian Ibu (AKI) dan Angka Kematian Bayi (AKB). Strategi untuk mencapai peningkatan profesional tenaga bidan dalam upaya menghasilkan pelayanan prima dan berkualitas dalam bidang kesehatan ibu dan anak yang lebih baik, maka diperlukan pendidikan diploma III kebidanan. Pendidikan diploma III kebidanan berpedoman pada kurikulum nasional tahun 2002, dimana kurikulum berorientasi ke arah kurikulum berbasis kompetensi yang mempunyai tujuan 
mencapai lulusan yang memenuhi standar kualifikasi profesi.

Proses pembelajaran di program studi Diploma III Kebidanan Poltekkes Tanjungkarang dalam rangka mencapai kompetensi dilakukan secara teori maupun praktek, baik praktek di laboratorium maupun praktik lapangan. Kompetensi inti bidan indonesia tersebut terbagi menjadi 5 kelompok kompetensi yang disesuaikan dengan kelompok mata kuliah yang diatur dalam Surat Keputusan Mendiknas 232/U/2000. Kompetensi yang ketiga yaitu: melaksanakan asuhan kebidanan secara profesional kepada wanita dalam siklus kehidupannya (remaja, pra perkawinan, ibu hamil, ibu bersalin, nifas, klimakterium, menopause dan masa antara asuhan neonatus, bayi dan anak balita ) di semua tatanan pelayanan kesehatan di institusi dan komunitas. Berdasarkan tuntutan kompetensi tersebut diperlukan pengalaman belajar di laboratorium. Laboratorium merupakan tempat melakukan aktifitas untuk menunjang proses pembelajaran keterampilan, yang ditunjang oleh tersedianya referensi, serta pengembangan metode, perangkat lunak, peraturan, dan prosedur praktikum.

Untuk dapat menghasilkan tenaga bidan yang mempunyai kompetensi sesuai dengan yang diharapkan tersebut maka sangatlah dibutuhkan pengelolaan pendidikan yang berkualitas. Usaha mencapai kualitas dalam konteks pendidikan, saat ini telah berkembang sebuah pendekatan, khususnya dalam proses manajerial, yaitu Total Quality Management (TQM). TQM merupakan perluasan dan pengembangan dari jaminan mutu (quality assurance). TQM adalah tentang sebuah usaha menciptakan sebuah kultur mutu, yang mendorong sebuah organisasi dan semua anggota/stafnya untuk memuaskan pelanggan. Program peningkatan mutu harus berorientasi kepada kebutuhan/harapan pelanggan, maka layanan pendidikan suatu lembaga haruslah memperhatikan masing-masing pelanggan di atas. Kepuasan dan kebanggaan dari pelanggan sebagai penerima manfaat layanan pendidikan harus menjadi acuan bagi program peningkatan mutu layanan pendidikan.

Berdasarkan hasil studi pendahuluan yang dilakukan terhadap beberapa mahasiswa pada bulan Desember 2015 terhadap pembelajaran praktik laboratorium, dikatakan bahwa mahasiswa merasakan ruangan yang kurang luas dan panas untuk praktikum, alat - alat praktikum yang masih cukup terbatas, model panggul dan boneka bayi yang rusak dan jadwal praktek laboratorium yang kadang kala bersamaan antara mata kuliah satu dengan yang lain, sehingga salah satu kelas harus melaksanakan praktik di ruang kelas. Pembelajaran praktikum ini selalu dilaksanakan untuk mencapai kompetensi tenaga bidan namun sampai saat ini belum pernah dilakukan pengkajian bagaimana wujud dari pembelajaran praktik laboratorium di prodi DIII kebidanan, sebagai masukan untuk peningkatan mutu pembelajaran praktik laboratorium. Penelitian ini akan menganalisis mutu pembelajaran praktik laboratorium sebagai upaya peningkatan mutu praktikum asuhan kebidanan di Prodi DIII Kebidanan Poltekes Tanjungkarang.

\section{METODE PENELITIAN}

Penelitian ini dilakukan dengan menggunakan penelitian deskriprif kualitatif dengan jenis studi kasus. Lokasi penelitian adalah Poltekkkes Tanjungkarang, khususnya pada Program Studi Diploma III Kebidanan Tanjungkarang. Subyek dari penelitian ini adalah semua unsur yang terlibat dalam kegiatan pelaksanaan pembelajaran praktik laboratorium. Tehnik pengambilan informan yang digunakan adalah purposive sampling. Tehnik sampling yang digunakan dalam penelitian ini adalah snowball sampling. Metode mengumpulkan data dalam penelitian ini menggunakan tehnik wawancara, observasi dan studi dokumentasi Analisa data dalam penelitian ini menggunakan analisa model interaktif. Analisis interaktif dilakukan melalui reduksi data, display data, penarikan kesimpulan dan peyusunan rekomendasi.

\section{HASIL}

\section{Perencanaan Pembelajaran Praktik Laboratorium}

Perencanaan pembelajaran pratik laboratorium tiap mata kuliah sudah dituangkan dalam silabus mata kuliah asuhan kebidanan yang disusun oleh dosen penanggung jawab mata kuliah. Penyusunan rencana pelaksanaan pembelajaran dilakukan secara serentak oleh seluruh dosen penangung jawab mata kuliah dengan melakukan workshop bersama sebelum semester berjalan. Hasil telaah perencanaan pembelajaran praktikum asuhan kebidanan yang telah dibuat, belum terinci dengan jelas dan sistematis, perencanaan belum mengambarkan tujuan, sistem pelaksanaan, evaluasi dan jadwal yang jelas, pada perencanaan hanya memfokuskan pada persiapan prosedur yang 
harus dikuasi oleh mahasiswa. Di dalam perencanaan belum dibuat panduan pelaksanaan praktikum yang harus diikuti oleh mahasiswa, belum terincinya persiapan praktikum yang akan dilaksanakan, mulai dari persiapan alat-alat yang akan digunakan, tempat pelaksanaan praktikum, jadwal pelaksanaan praktikum, kapan dan berapa kali mahasiswa akan melakukan redemonstrasi kembali tentang praktikum yang akan dilakukan dan siapa pembimbing yang mendampingi mahasiswa praktikum. Akibat tidak adanya perencanaan yang jelas maka pelaksanaan pembelajaran tidak jelas arahnya. Pada perencanaan seharusnya sudah dibuat secara rinci dan jelas karena perencanaan merupakan pijakan awal melakukan suatu kegiatan.

\section{Pelaksanaan Pembelajaran Praktik Laboratorium \\ Pelaksanaan pembelajaran praktik} laboratorium belum dapat dilaksanakan secara optimal oleh dosen pembimbing praktikum, banyak kendala yang dihadapi diantaranya adalah : saat pelaksanaan praktikum terkadang ada beberapa alat praktikum yang belum disediakan, mahasiswa bolak-balik mengebon alat ke petugas laboratorium sehingga banyak waktu yang terbuang hanya untuk mempersiapkan alat saja. Jadwal pelaksanaan pratik laboratorium terkadang bersamaan dengan praktikum asuhan kebidanan lainnya sehingga tempat pelaksanaan praktikum tidak dilakukan di ruang praktikum (laboratorium) tetapi dilakukan di ruang kelas. Terbatasnya alat-alat praktikum kebidanan dengan jumlah mahasiswa yang akan melaksanakan praktikum kurang memadai, sehingga mahasiswa menunggu lama mendapatkan kesempatan meredemonstrasikan ulang keterampilan yang akan mereka lakukan. Jadwal praktikum mahasiswa yang tidak terjadwal secara rinci, mengakibatkan mahasisa saling berebutan untuk melakukan praktikum. Pembimbing praktikum yang tidak selalu mendampingi mahasiswa, sehingga disaat melakukan latihan mengakibatkan mahasiswa bingung untuk melaksanakan praktikum karena tidak ada tempat untuk bertanya saat mengalami kendala, mahasiswa hanya mengandalkan cek lys yang tersedia yang mengakibatkan mahasiswa melakukan tindakan praktik laboratorium dengan persepsi nya masing-masing.

Berdasarkan hasil analisis data didapatkan : 1) sebelum pelaksanaan praktikum, mahasiswa belajar secara mandiri tanpa ada pendampingan dari dosen pembimbing praktikum, sehingga bila ada kesulitan tidak ada yang mengarahkan; 2) tidak dilakukannya pretest sebelum pelaksanaan pembelajaran praktikum, sehingga mahasiswa tidak mempersiapkan diri terlebih dahulu sebelum pembelajaran praktikum; 3) Tidak adanya jadwal yang pasti untuk pembelajaran praktikum; 4) prosedur praktikum yang diterapkan belum menggambarkan untuk mempersiapkan mahasiswa baik dari segi pengetahuan (konsep teori) maupun psikomotor secara optimal.

\section{Evaluasi Pembelajaran Praktik Laboratorium \\ Evaluasi yang dilakukan dalam} pembelajaran praktikum kebidanan hanya dilakukan pada saat ujian akhir semesteran saja, patokan keterampilan yang akan diujikan berpedoman pada ceklist/format SOP asuhan kebidanan yang akan diujikan. Sistem evaluasi bagi mahasiswa yang mengikuti pembelajaran praktikum dan bagi mahasiswa yang harus mengulang belum ada. Cara penilaian untuk menentukan apakah mahasiswa sudah kompeten atau belum hanya dengan menggunakan ceklist, dan tidak dilakukan umpan balik setelah melakukan praktikum. Pada mahasiswa yang belum kompeten tidak dilakukan remidial oleh dosen pembimbing praktikum. Dosen hanya memberi kesempatan pada mahasiswa untuk mengulang kembali pada keterampilan yang belum di capai praktikum secara mandiri tanpa didampingi oleh dosen.

Hasil pengamatan penulis saat dilakukan ujian praktikum oleh dosen pada ujian akhir semester, terkadang mahasiswa dibuat gugup dan bingung untuk melakukan prosedur tindakan yang akan dilakukan, walaupun sudah tersedia ceklist/ SOP yang akan di lakukan sesuai dengan jenis keterampilan yang akan diujikan. Hal ini disebabkan masih ada dosen yang melakukan penilaian terhadap mahasiswa yang diuji mempunyai persepsi yang berbeda dengan prosedur/ceklist yang telah tersedia dan pada saat ujian praktikum berlangsung masih ada dosen yang membentak mahasiswa, sehingga mahasiswa merasa takut untuk melakukan praktikum kebidanan yang sedang diujikan.

Evaluasi selama proses pembelajaran praktikum tidak dilakukan oleh dosen, sehingga tidak diketahui secara pasti apakah setiap mahasiswa sudah mampu untuk memperaktikan asuhan kebidanan yang diajarkan dosen. Pre-test sebelum pelaksanaan pembelajaran praktikum tidak dilakukan, sehingga mahasiswa tidak mempersiapkan diri terlebih dahulu sebelum pembelajaran praktikum. 


\section{Mutu Pembelajaran Praktikum}

\section{a) Kehandalan}

Langkah-langkah yang dilakukan dosen saat melakukan pembelajaran praktikum adalah : membuka pembelajaran praktikum, kemudian menjelaskan tujuan pembelajaran, serta metode yang akan digunakan, metode yang akan digunakan adalah demonstrasi dan redemonstrasi. Sebelum melaksanakan prosedur asuhan kebidanan dosen menjelaskan kepada mahasiswa alat-alat yang akan digunakan dalam praktikum, hal-hal yang harus dipersiapkan sebelum melakukan tindakan lalu dosen mendemonstrasikan langkah - langkah keterampilan yang akan dilakukan sesuai dengan SOP. Kemudian dosen meminta salah satu mahasiswa maju ke depan secara sukarela untuk meredemonstrasi prosedur/ langkahlangkah yang telah diajarkan. Selanjutnya dosen memberi kesempatan pada mahasiswa untuk bertanya, selesai tanya jawab dosen menutup pembelajaran. Untuk mencapai kompetensi keterampilan praktikum asuhan kebidanan dilakukan oleh masing-masing mahasiswa tanpa ada jadwal yang rinci oleh dosen penanggung jawab mata ajaran, mahasiswa mencari waktu latihan sendiri. Pelaksanaan latihan yang dilakukan oleh mahasiswa terkadang tidak dibimbing oleh dosen pengampu mata ajaran. Tidak adanya pengawasan dan feed back latihan praktik asuhan kebidanan oleh dosen yang bersangkutan sehingga pencapaian target keterampilan asuhan kebidanan yang harus dicapai oleh mahasiswa tidak dapat dipantau dengan jelas. Dalam mempersiapkan alat-alat untuk praktikum dilakukan oleh tenaga laboratorium bersama-sama dengan mahasiswa, dosen tidak ikut serta menyediakan alat karena dosen akan datang jika alat-alat yang diperlukan sudah dipersiapkan terlebih dahulu.

\section{b) Daya Tanggap}

Pelayanan petugas laboratorium belum cukup tanggap dalam mempersiapkan tempat dan alat untuk kegiatan pembelajaran praktikum. Petugas laboratorium membantu mahasiswa dalam mempersiapkan alat-alat untuk praktikum, tetapi terkadang mahasiswa harus menunggu lama untuk meminjam alat-alat praktikum yang akan di gunakan hal ini disebabkan oleh karena alat peraktik yang dibutuhkan masih terpakai oleh kelas lain yang melakukan praktik asuhan kebidanan. Petugas laboratorium belum merespon dengan segera keluhan-keluhan yang disampaikan oleh mahasiswa. Petugas laboratorium hanya menyiapkan alat-alat yang diperlukan saja untuk praktik, sedangkan setting tempat/ ruangan praktik dilakukan oleh mahasiswa. Pada saat pembelajaran praktikum, masih ada dosen yang tidak cepat tanggap mengatasinya jika ada kesulitan yang dialami oleh mahasiswa.

\section{c) Kepastian Pembelajaran Praktikum}

Petugas sudah datang tepat waktu, akan tetapi tidak selalu bertugas setiap ada jadwal praktikum terutama bila pembelajaran praktikum dilaksanakan diluar jam kerja. Pelaksanaan pembelajaran praktikum belum tertata dengan rapi, karena belum tersedia panduan pembelajaran praktik laboratorium yang baku. Dosen melakukan pembelajaran praktikum terkadang tidak sesuai dengan jadwal praktikum, sehingga kadang-kadang mahasiswa tidak siap. Jadwal latihan praktikum asuhan kebidanan yang dilakukan mahasiswa secara mandiri belum ada.

\section{d) Empati Pembelajaran Praktikum}

Mahasiswa diberi kesempatan untuk melakukan praktikum diluar jam perkuliahan. Saat pelaksanaan pembelajaran praktikum terkadang dosen kurang memperhatikan mahasiswa apakah mahasiswa sudah mengerti atau belum tentang keterampilan yang sedang diajarkan. Dosen bersikap ramah dalam memberikan jawaban ketika mahasiswa bertanya. Petugas laboratorium kadang-kadang ramah, kadang kurang ramah dalam memberikan pelayanan kepada mahasiswa.

\section{e) Wujud Pembelajaran Praktikum}

Terdapat tiga ruangan untuk pelaksanaan praktik laboratorium yaitu ruangan untuk praktikum tehnik kebidanan dasar, ruangan untuk pelaksanaan asuhan kebidanan klinik dan asuhan kebidanan komunitas. Ruang laboratorium belum memenuhi kebutuhan untuk praktikum, dimana luas ruangan untuk pelaksanaan praktikum asuhan kebidanan tidak sesuai dengan jumlah mahasiswa yang akan melakukan praktikum. Ruang praktikum untuk asuhan kebidanan klinik kurang memadai karena disatukan dengan ruang praktikum asuhan kebidanan komunitas. Kenyamanan ruangan praktikum yang kurang, ruangan terasa panas (kurang sejuk). Pencahayaan ruangan yang cukup terang, bila praktikum dilakukan pada siang hari, sirkulasi udara dalam ruang praktikum cukup memadai. Kebersihan lantai, dinding, atap dan jendela cukup bersih. Alat-alat yang digunakan praktikum kadang-kadang ada yang dalam keadaan kurang bersih, sehingga mahasiswa harus membersihkannya terlebih dahulu sebelum 
menggunakan. Penataan alat-alat laboratorium masih kurang rapi, sehingga bila membutuhkan masih sulit untuk mencarinya. Alat-alat untuk praktikum khususnya untuk mata kuliah asuhan kebidanan masih kurang lengkap dan dalam jumlah yang terbatas. Belum tersusun paketpaket alat/ perlengkapan yang akan digunakan untuk setiap jenis keterampilan yang akan dipraktikan, dikarenakan jumlah alat yang sangat terbatas.

\section{Faktor Pendukung dan Penghambat dalam Pembelajaran Praktikum}

a) Faktor Pendukung

Letak ruang penyimpanan alat laboratorium yang strategis, sehingga memudahkan mahasiswa untuk menjangkaunya. Adanya cheklist/ SOP untuk setiap jenis keterampilan asuhan kebidanan yang akan diajarkan. Metode yang digunakan dalam pembelajaran praktikum ceramah tanya jawab demonstrasi dan redemonstrasi. Dalam evaluasi menggunakan PAP berdasarkan (cheklist), sehingga mahasiswa akan memiliki minimal kemampuan yang sama. Adanya tenaga khusus yang mengelola laboratorium, sehingga mahasiswa dapat menggunakan ruang laboratorium setiap jam kerja. Adanya dosen pembimbing praktikum dengan latar belakang pendidikan S2 kebidanan sebanyak 3 dosen, dan motivasi mahasiswa yang tinggi untuk melakukan latihan pembelajaran praktikum secara mandiri maupun tutorial antar teman.

\section{b) Faktor Penghambat}

Jumlah peralatan untuk praktik keterampilan asuhan kebidanan belum sesuai antara jumlah alat yang tersedia dengan jumlah mahasiswa yang akan melakukan praktikum. Belum adanya buku panduan yang baku untuk pembelajaran praktikum. Rasio dosen pembimbing praktikum dengan jumlah mahasiswa tidak sesuai. Belum dilaksanakannya pretest maupun post test pada jenis kompetensi yang akan dilakukan praktikum. Belum semua penangungjawab mata ajaran melakukannya persamaan persepsi bagi dosen pembimbing praktikum. Ruangan yang kurang memadai dan representatif untuk praktikum (ruangan praktikum yang panas dikarenakan air condesioner yang tidak befungsi secara maksimal, tidak seimbangnya ruang praktikum asuhan kebidanan dengan jumlah mahasiswa yang akan melakukan praktikum). Jadwal praktik laboratorium yang kadang kala bersamaan antara asuhan kebidanan satu dengan yang lain dan Tidak tersedianya lemari (loker) tempat menyimpan tas (buku) mahasiswa saat mahasiswa melakukan peraktik laboratorium.

\section{PEMBAHASAN}

Dalam rangka melaksanakan peningkatan kualitas mutu pembelajaran praktik laboratorium asuhan kebidanan terhadap mahasiswa DIII kebidanan, diperlukan desain pembelajaran dengan pendekatan yang dikenal dengan metode PDCA (Plan-Do-Chek-Act). Metode ini pertama kali dikembangkan oleh Walter Sheward dan divisualisasikan oleh Deming. PDCA adalah siklus yang menekankan proses perbaikan terus menerus dan berkelanjutan. Gambar siklus PDCA dapat dilihat dalam gambar berikut:

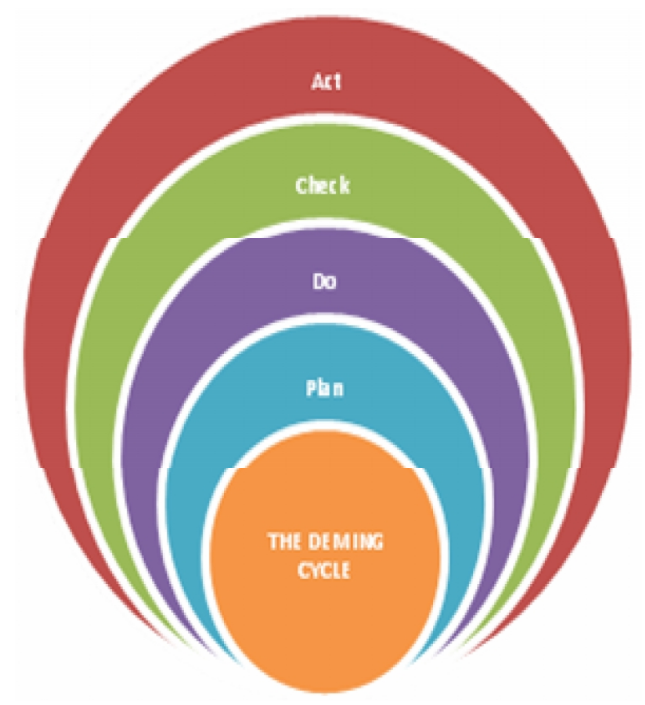

\section{Gambar 1. The Deming Cycle}

Konteks transformasi PDCA ke dunia pendidikan bisa diambil tahapan sebagai berikut :

1. Plan, Untuk meningkatkan mutu pembelajaran praktik laboratorium kebidanan perlu dilakukan perencanaan berisi penentuan proses pembelajaran yang mana yang perlu diperbaiki, menentukan perbaikan peraktik laboratorium kebidanan apa yang dipilih, dan menentukan data dan informasi baik dari dosen, petugas laboratorium dan mahasiswa yang akan di jadikan bahan masukan bagi penentu kebijakan dalam menentukan bagian mana yang diperlukan untuk perbaikan proses tersebut. Perencanaan pembelajaran praktikum untuk mata kuliah Asuhan Kebidanan perlu disusun secara sistimatis. Perencanaan merupakan pijakan awal dalam melakukan suatu kegiatan. Di dalam perencanaan sudah ditentukan tujuan pembelajaran, alur pelaksanaan yang harus diikuti oleh mahasiswa, sistem evaluasi bagi mahasiswa yang mengikuti pembelajaran dan 
bagi mahasiswa yang belum kompeten pada praktikum yang pertama.

Menurut Nursalam (2008) proses pembelajaran praktikum melalui tahapan sebagai berikut: 1) Persiapan rancangan pembelajaran dalam rangka membantu peserta didik melaksanakan tugas belajar. Pada tahap ini ditekankan pada perencanaan pembelajaran yang memenuhi kebutuhan belajar peserta didik, termasuk sumber yang sesuai dengan jumlah peserta didik dan pengajar, mencoba peralatan yang akan digunakan untuk demonstrasi/ redemonstrasi, merancang "lay out”, merencanakan ruang praktikum, membuat makalah, pengaturan tempat duduk. 2) Penerapan Berbagai metode pembelajaran yang memungkinkan peserta didik dapat menyelesaikan tugas pembelajaran sesuai dengan tujuan yang diinginkan. 3) Evaluasi terhadap hasil pencapaian tujuan pembelajaran praktikum yang telah dilakukan, dan evaluasi terhadap kemampuan peserta didik.

Menurut Nursalam (2008) tugas dosen dalam rangka pembelajaran praktik laboratorium adalah : 1) Mendesain dan mengelola sebuah kegiatan praktikum agar tujuan instruksionalnya jelas, isi dan urutan kegiatan terarah dengan baik, relevan dengan tuntutan tugas profesi lulusannya dan dirancang sedemikian rupa sehingga merupakan pengalaman belajar yang menarik serta menyenangkan bagi mahasiswa. 2) Merencanakan, melaksanakan dan mengevaluasi suatu praktikum. Langkah ini merupakan hal yang kompleks dan rumit. Langkah pendidik selanjutnya adalah menetapkan alat dan bahan yang dibutuhkan baik jenis maupun jumlahnya untuk pelaksanaan kegiatan praktikum (sesuai dengan Standar Laboratorium), kemudian menyusun cara kerja (SOP dan instruksi kerja) dimana SOP/IK menguraikan secara rinci, berurutan dan sistimatis langkah-langkah yang harus dilakukan untuk menguasai keterampilan yang dipraktikan dalam pencapaian kompetensi. Langkah selanjutnya adalah menyusun instrumen penilaian praktik laboratorium yang disusun dalam bentuk ceklist/ lembar observasi yang mengacu pada perencanaan pembelajaran dan Standar Operasional Prosedur (SOP). (Pusdiknakes, 2010).

2. Do, beirisi pengumpulan data dasar tentang jalannya proses pembelajaran praktik laboratorium asuhan kebidanan, dan bagaimana implementasi perubahan yang dikehendaki apakah sesuai dengan plan yang telah direncanakan, mengumpulkan data tentang jalannya proses pembelajaran praktik laboratorium kebidanan diperlukan untuk mengetahui apakah diperlukan perbaikan atau tidak. Dunkin dan Biddle (Majid, 2007) yang menyatakan bahwa pengelolaan pembelajaran merupakan suatu proses penyelenggaraan interaksi peserta didik dengan pendidik dan sumber belajar pada suatu lingkungan belajar. Dalam pelaksanaan proses pembelajaran banyak faktor yang diperhatikan, tidak langsung pada inti kegiatan, melainkan dari kesiapan mahasiswa, dosen pembimbing praktikum, metode yang digunakan, serta media yang digunakan selama proses pembelajaran praktikum. Pengalaman belajar praktikum (laboratorium) merupakan tahapan proses pembelajaran yang penting untuk mempersiapkan peserta didik dalam melaksanakan pembelajaran praktik di lahan praktek/ klinik. Dimana pembelajaran praktikum (laboratorium) lebih menekankan pada penguasaan aspek keterampilan, baik keterampilan dasar maupun keterampilan teknis kesehatan. Dengan menguasai aspek keterampilan di laboratorium, maka akan memberikan bekal/ persiapan peserta didik untuk mengikuti pembelajaran di klinik. (Pusdiknakes, 2010).

3. Check, berisi langkah dosen untuk menafsirkan hasil implementasi (berhasil atau tidak) atau upaya dosen untuk memperoleh pengetahuan baru tentang proses pembelajaran praktik laboratorium kebidanan yang telah dilaksanakan. Hal ini merupakan tanggung jawab dosen yang telah menjadi tugas dan wewenangnya. Standar penilaian pada pendidikan tenaga kesehatan untuk pembelajaran praktikum adalah tes unjuk kerja/ tes performance, yaitu tes yang dilaksanakan dengan mengamati kegiatan atau hasil pekerjaan peserta didik. Tes ini digunakan untuk mengukur kompetensi peserta didik di dalam melakukan suatu tindakan. Standar penilaian pada pembelajaran praktikum berorientasi pada kompetensi dasar dan metode pembelajaran yang digunakan. Dalam melakukan penilaian praktikum harus tersedia : a. Instrumen penilaian dalam bentuk ceklist/ lembar oservasi yang mengacu pada perencanaan pembelajaran dan Standar Operasional Prosedur (SOP), b. Instrumen penilaian harus mengandung unsur aspek pengetahuan, sikap dan keterampilan, c. Indikator penilaian harus dikomunikasikan kepada peserta didik, d. Harus diberikan feed back/ umpan balik hasil penilaian kepada peserta didik, e. Indikator penilaian harus berorientasi kepada kompetensi dasar dan f. Penilaian dapat 
diulang sampai peserta didik kompeten (Pusdiknakes, 2010).

4. Act, berupa pengambilan keputusan perubahan dalam pembelajaran praktik laboratorium kebidanan mana yang akan diimplementasikan, penyusunan prosedur pembelajaran praktikum yang baku, perbaikan ke arah yang lebih baik tentang hal-hal yang menjadikan faktor penghambat pelaksanaan praktikum, mengatasi dan mencari solusi terhadap permasalahan-permasalahan yang timbul dalam ruang lingkup proses praktikum asuhan kebidanan dan melakukan pemantauan secara kontinyu dan berkesinambungan.

\section{Upaya peningkatan mutu} pembelajaran praktik asuhan kebidanan, peneliti menggunakan pendekatan empiris yang normatif. Terdapat lima faktor dominan atau penentu dalam mutu pelayanan jasa, yang pada akhirnya menjadi penentu peningkatan kualitas mutu. Strategi meningkatkan mutu pembelajaran praktikum tersebut, terdapat dalam lima dimensi pokok yang digunakan dalam menilai kualitas pelayanan yaitu :

\section{a. Kehandalan (Reliability)}

Yaitu kemampuan untuk memberikan pelayanan sesuai dengan yang dijanjikan dengan segera, akurat, dan memuaskan. Reliability mencakup 2 hal pokok yaitu konsistensi kerja (performance) dan kemampuan untuk dapat dipercaya (dependability). Hal ini berarti bahwa pengelola pendidikan memberikan pelayanan secara tepat semenjak saat pertama (right the first time). Selain itu juga berarti bahwa dosen yang bersangkutan memenuhi janjinya, misalnya menyampaikan layanan sesuai dengan jadwal yang disepakati.

Berdasarkan hasil penelitian menggunakan wawancara menunjukkan bahwa dosen tidak memberikan panduan praktikum tetapi hanya ceklist. Hal ini disebabkan karena belum adanya kebijakan yang menegaskan bahwa semua pembelajaran di laboratorium harus disertai dengan pembuatan panduan praktikum. Sebaiknya dalam pembelajaran praktikum dibuat Prosedur Operasional Standar (Standard Operating Prosedures= SOP) atau instruksi kerja. Prosedur ini bersifat operasional dan mengikat bagi semua pengguna laboratorium.

Jenis SOP/ instruksi kerja yang perlu adalah: (1) Pedoman pelaksanaan praktikum, (2) Prosedur Tetap (Protap) pelaksanaan praktikum tiap mata kuliah terkait, (3) Dokumentasi berupa absensi peserta didik, absensi kehadiran dosen, objek/materi praktikum dan (4) Adanya sistem pelaporan dan dokumentasi dari setiap kegiatan praktikumdi masing-masing laboratorium, baik persemester maupun pertahun.

Tugas dosen dalam praktikum adalah mendesain dan mengelola sebuah kegiatan praktikum agar tujuan instruksionalnya jelas, isi dan urutan kegiatan terarah dengan baik, relevan dengan tuntutan tugas profesi. Untuk meningkatkaan mutu pembelajaran peraktik laboratorium kebidanan hendaknya dosen melakukan langkah-langkah sebagai berikut: (1) Sebelum PBL dosen menjelaskan secara teori terlebih dahulu dengan benar sehingga tidak menimbulkan bias memahami teori PBL, (2) Sebelum PBL hendaknya dosen menjelaskan tujuan umum dan khusus PBL dengan benar sehingga mahasiswa bisa memahami tujuan umum dan khusus PBL, (3) Dosen hendaknya memberikan panduan/checklist setiap perasat praktik laboratorium, sesuai dengan Standar Operasional Prosedur (SOP), (4) Dosen menggunakan tehnik demonstrasi dan Simulasi dengan benar sehingga Mahasiswa dapat melaksanakan praktikum sesuai dengan urutan urutan yang ada, (5) Dosen hendaknya turut serta bersama dengan mahasiswa mempersiapkan alat dan bahan untuk PBL, sehingga dalam melaksanakan praktikum asuhan kebidanan menjadi lancar tanpa kendala, (6) Petugas selalu menyiapkan tempat dan alat dengan baik sehingga mahasiswa tidak mengalami kendala pada waktu pembelajaran praktik di laboratorium, (7) Petugas laboratorium hendaknya sudah menyediakan sarana prasarana dengan lengkap sesuai dengan standar alat yang harus disiapkan untuk masing-masing jenis-jenis keterampilan, caranya petugas laboratorium sudah mempunyai daftar paket peraktik asuhan kebidanan dan alat-alat yang akan di gunakan untuk masing-masing jenis keterampilan yang akan digunakan sudah disiapkan dalam bentuk paket, sehingga saat melaksanakan pembelajaran praktek laboratorium sudah tersedia alat yang sesuai dengan standar yang diperlukan.

\section{b. Daya tangga (Responsiveness)}

Daya tanggap (responsiveness) yaitu keinginan para dosen dan petugas laboratorium untuk membantu para pelanggan dan memberikan pelayanan dengan tanggap dan memberikan jasa dengan cepat dan bermakna serta kesediaan mendengar dan memberikan pelayanan dengan tanggap dan memberikan jasa dengan cepat dan bermakna kesediaan mendengar dan mengatasi keluhan yang diajukan pelanggan. Dalam praktik laboratorium daya tanggap oleh dosen dan petugas laboratorium belum dapat dilaksanakan secara optimal, 
karena dosen dan petugas laboratorium yang lain belum tanggap terhadap kebutuhan mahasiswa. Untuk memuaskan para pelanggan (mahasiswa) hendaknya para dosen dan petugas laboratorium untuk dapat memenuhi harapan pelanggan dengan cara memberikan pelayanan dengan tanggap dan memberikan jasa dengan cepat dan bermakna serta kesediaan mendengar dan mengatasi keluhan yang diajukan mahasiswa, misalnya penyediaan sarana yang sesuai untuk menjamin terjadinya proses yang tepat. Hal-hal yang harus dilakukan oleh dosen dan petugas laboratorium adalah sebagai berikut: (1) Petugas laboratorium menyiapkan tempat dan alat-alat dengan segera pada saat ada praktikum, (2) Petugas laboratorium cepat memberi tanggapan bila ada kesulitan/ keluhan mahasiswa tentang praktikum, (3) Pengelola Prodi Kebidanan cepat memberi tanggapan bila ada kesulitan / keluhan dari dosen ataupun dari mahasiswa, dan (4) Dosen dengan segera menanggapi mahasiswa bila ada mahasiswa yang mengalami kesulitan dalam proses pengajaran peraktik laboratorium.

\section{c. Kepastian (Assurance)}

Dimensi kepastian/ assurance ini merupakan gabungan dari dimensi: (1) Kompetensi (competence), artinya keterampilan dan pengetahuan yangdimiliki oleh para dosen dan pengelola pendidikan untuk melakukan pelayanan, (2) Kesopanan (courtesy), yang meliputi keramahan, perhatian dan sikap para Dosen dan karyawan dan (3) Kredibilitas (credibility), meliputi hal-hal yang berhubungan dengan kepercayaan kepada pendidikan seperti reputasi, prestasi dan sebagainya.

Pembelajaran praktikum akan berhasil jika ditunjang oleh persiapan yang matang oleh dosen, meliputi kepastian jadwal pembelajaran praktikum sudah diberikan jauh hari sebelum pembelajaran praktikum dilaksanakan, petugas laboratorium ada di tempat ketika pelaksanaan pembelajaran praktikum, pengelola program studi melengkapi alat-alat yang dibutuhkan di laboratorium berdasarkan kompetensi yang akan dicapai oleh mahasiswa. Hal - hal yang seharusnya dilakukan oleh dosen dan petugas laboratorium dalam rangka meningkatkan mutu pembelajaran di laboratorium kebidanan adalah sebagai berikut: (1) Petugas laboraorium hendaknya bertugas setiap saat sesuai jadwal PBL, (2) Petugas laboratorium datang lebih awal pada waktu ada praktikum sehingga mahasiswa tidak mengalami kesulitan dalam mempersiapkan alat-alat praktikum yang akan digunakan, (3) Petugas laboratorium menepati janji bila ada jadwal diluar jam kuliah, (4) Dosen pengajar di laboratorium hendaknya sesuai dengan jadwal yang telah ditentukan, (5) Pengelola menyediakan sarana prasana yang mencukupi sesuai kebutuhan praktik laboratorium untuk mahasiswa pada mata kuliah yang ada praktikumnya.

\section{d. Empati (Emphaty)}

Pengembangan terhadap empati harus dilakukan karena dengan empati menjamin adanya kemudahan dalam melaksanakan hubungan, komunikasi yang baik, perhatian pribadi dan memahami kebutuhan para mahasiswa dalam pembelajaran praktikum. Dengan demikian pihak institusi Program Studi Diploma III Kebidanan Tanjungkarang harus mempertahankan bahkan lebih meningkatkan kondisi yang berkaitan dengan empati dalam rangka mempertahankan dan meningkatkan mutu pembelajaran praktikum.

Empati adalah kemudahan dalam melaksanakan hubungan, komunikasi yang baik, perhatian pribadi dan memahami kebutuhan pelanggan. Dimensi empati merupakan gabungan dari dimensi akses, komunikasi dan pemahaman kepada pelanggan. (Engkoswara, 2010). Dosen harus memiliki sifat empati dimana harus bersikap ramah, memberi kesempatan kepada mahasiswa untuk bertanya dan dosen memberikan jawaban sesuai dengan apa yang diinginkan oleh mahasiswa, dosen bersedia meluangkan waktu di luar jam perkuliahan untuk membimbing mahasiswa dalam pembelajaran praktikum, sehingga tujuan pembelajaran praktikum akan tercapai dan mahasiswa akan lebih terampil untuk kompetensi asuhan kebidanan.

Petugas laboratorium dan pengelola Program Studi Diploma III Kebidanan Tanjungkarang juga harus memiliki rasa empati dalam memberikan pelayanan kepada mahasiswa, sehingga petugas laboratorium dan pengelola Program Studi Diploma III Kebidanan dapat bersikap ramah dalam melayani mahasiswa dan bersedia meluangkan waktu untuk mendengarkan keluhan mahasiswa.

Dimensi emphaty ini merupakan gabungan dari dimensi: (1) Akses (accces), meliputi kemudahan untuk memanfaatkan jasa yang ditawarkan, (2) Komunikasi (communication), merupakan kemampuan melakukan komunikasi untuk menyampaikan informasi kepada mahasiswa atau memperoleh masukan dari mahasiswa dan (3) Pemahaman kepada mahasiswa (Understanding the Customer), meliputi usaha pengelola pendidikan untuk 
mengetahui dan memahami kebutuhan dan keinginan mahasiswa. Hal-hal yang perlu dilakukan oleh dosen dan petugas laboratorium adalah sebagai berikut: Tugas dosen (1) Dosen memberi kesempatan mahasiswa belajar di laboratorium diluar jadwal kuliah, (2) Dosen bersedia meluangkan waktu untuk mendengarkan keluhan mahasiswa, (3) Dosen bersikap ramah dalam memberikan jawaban ketika mahasiswa bertanya, (4) Dosen bersikap tanggap dan kooperatif dalam melayani mahasiswa dan (5) Dosen bersedia meluangkan waktu diluar jadwal ketika mahasiswa meminta bimbingan diluar jam mengajar.

Tugas tenaga bantu laboratorium sebagai berikut : (1) Menyiapkan alat-alat untuk percobaan peserta didik dan demonstrasi oleh dosen dan peserta didik, (2) Memelihara alat-alat dan memeriksa jumlah alat-alat dan bahan, (3) Menyiapkan bahan-bahan yang habis pakai, (4) Membantu dosen di dalam laboratorium, dan (5) Memeriksa keadaan alat-alat dan memisahkan alat-alat yang baik dan yang rusak dan melaporkan keadaan itu kepada penanggung jawab laboratorium. Kegiatan yang dilaksanakan pengelola di laboratorium: (1) Memberikan pelayanan laboratorium bagi pengguna; (2) Mengadakan pertemuan periodik untuk komunikasi antar dosen; (3) Menjadwalkan penggunaan laboratorium; (4) Membuat jadwal pemeliharaan alat laboratorium; (5) Melakukan pemeliharaan keadaan laboratorium secara keseluruhan; (6) Melakukan pemeliharaan preventif alat dan bahan; (7) Melakukan Kalibrasi terhadap peralatan laboratorium sesuai dengan spesifikasi, (8) Melakukan perbaikan alat rusak yang masih dapat diperbaiki di laboratorium; (9) Melakukan inventarisasi alat dan bahan untuk mengetahui jumlah alat yang ada, yang masih baik, dan yang rusak; (10) Membuat dan mengusulkan rencana anggaran biaya laboratorium/ bengkel kerja; (11) Menerima dan memeriksa alat dan bahan yang diterima; (12) Melakukan langkah-langkah yang diperlukan agar kegiatan - kegiatan di dalam laboratorium berlangsung aman, terhindar dari kecelakaan dan (13) Mencatat (dalam buku harian) kejadian-kejadian yang dianggap penting untuk dicatat.

\section{e. Berwujud (Tangibles)}

Wujud (tangible) adalah bukti fisik dari pelayanan, bisa berupa fasilitas fisik, perlengkapan dan peralatan yang dipergunakan dan sarana komunikasi. Selain fasilitas fisik yang bersifat tangible (terlihat), salah satu faktor yang mempengaruhi belajar adalah alat bantu dan fasilitas belajar, yang dimaksud dengan alat bantu adalah alat-alat yang digunakan oleh pendidik (dosen/ instruktur) dalam menyampaikan bahan pelajaran. Basic service sangat erat dengan reliabilitas. Pelanggan menginginkan basic service, mengharapkan pelayanan yang fundamental dan bukan sekadar janji-janji.

Hasil penelitian menunjukkan bahwa wujud dari ruang laboratorium yang ada di Program Studi Diploma III Kebidanan Tanjungkarang belum sesuai dengan standar, fasilitas dan jumlah peralatan yang tersedia juga belum mencukupi dan untuk penataan alat-alat laboratorium kurang tertata dengan rapi. Untuk meningkatkan mutu pembelajaran praktikum dan meningkatkan kepuasan mahasiswa maka peningkatan dalam penyediaan fasilitas fisik (wujud) harus lebih ditingkatkan. Hal ini sesuai dengan teori bahwa fasilitas fisik termasuk alat bantu merupakan faktor yang mempengaruhi proses belajar mengajar, dan benda asli atau benda tiruan merupakan alat bantu yang mempunyai intensitas paling tinggi untuk mempersepsikan bahan pengajaran. (Notoatmodjo, 2003).

Sarana dan prasarana yang dibutuhkan dalam pembelajaran praktikum secara langsung dapat dilihat dan dinilai oleh mahasiswa, apakah sarana dan prasarana tersebut sesuai dengan harapannya agar dapat melakukan pembelajaran praktikum dengan baik atau tidak. Salah satu faktor yang mempengaruhi proses belajar adalah fasilitas yang tersedia serta alat peraga yang berasal dari benda asli atau tiruan mempunyai intensitas yang paling tinggi untuk mempersepsikan bahan pengajaran (Notoatmodjo, 2003).

Suatu laboratorium dapat berfungsi dengan efektif dan efisien harus memperhatikan hal-hal terkait persyaratan minimal sebagai berikut: (1) Jenis dan jumlah peralatan, serta bahan habis pakai berdasarkan pada kompetensi yang akan dicapai yang dinyatakan dalam rasio antara alat dengan peserta didik, (2) Bentuk/ desain laboratorium harus memperhatikan aspek keselamatan atau keamanan, (3) Laboratorium agar aman dan nyaman bagi peserta didik dan instruktur harus : (a). Keadaan ruang harus memungkinkan dosen/instruktur dapat melihat semua peserta didik yang bekerja di dalam laboratorium itu tanpa terhalang oleh perabot atau benda-benda lain yang ada di dalam laboratorium tersebut, (b). Peserta didik harus dapat mengamati demonstrasi/ simulasi dari jarak maksimal $2 \mathrm{~m}$ dari meja demonstrasi, (c). Lantai laboratorium tidak boleh licin, harus mudah 
dibersihkan, dan tahan terhadap tumpahan bahanbahan kimia, (d). Alat-alat atau benda-benda yang dipasang di dinding tidak boleh menonjol sampai ke bagian ruang tempat peserta didik berjalan dan sirkulasi alat, (e). Tersedianya buku referensi penunjang praktik.Tersedianya air mengalir (kran), (f). Meja praktikum harus tidak tembus air,tahan asam dan basa(Terbuat dari porselin), (g). Tersedia ruang dosen/ instruktur, (h). Tersedianya kebutuhan listrik seperti stopkontak (mains socket). (4). Bentuk Ruang : (a). Bentuk ruang laboratorium sebaiknya bujur sangkar atau mendekati bujur sangkar atau bisa juga berbentuk persegi panjang, (b). Bentuk bujur sangkar memungkinkan jarak antara dosen dan peserta didik dapat lebih dekat sehingga memudahkan kontak antara dosen/ instruktur dan peserta didik. (5). Luas Ruang: (a). Luas ruang praktik laboratorium harus memenuhi persyaratan, yaitu: 1 orang peserta didik memerlukan ruang kerja minimal $2,5 \mathrm{~m}^{2}$. Disediakan ruang kosong antara tembok dan meja kerja sekitar $1.7 \mathrm{~m}$ untuk memudahkan dan mengamankan sirkulasi alat dan peserta didik di laboratorium. Jarak antara ujung meja yang berdampingan sebaiknya tidak kurang dari 1.5 $\mathrm{m}$, sehingga peserta didik dapat bergerak leluasa pada waktu bekerja dan pada waktu pindah atau memindahkan alat (bahan) dari satu tempat ke tempat lain. Luas ruang harus sebanding dengan banyaknya peserta didik dan jenis pendidikan, (b). Luas ruang penyimpanan alat dan bahan disesuaikan dengan jenis alat/ bahan yang ada di setiap jenis pendidikan.

\section{SIMPULAN}

1. Pembelajaran praktik laboratorium kebidanan yang dilaksanakan di laboratorium Prodi DIII Kebidanan Tanjungkarang dilakukan secara langsung oleh dosen mata kuliah banyak mengalami permasalahan : diantaranya adalah masalah perencanaan proses dan evaluasi pembelajaran praktik laboratorium.

2. Mutu pembelajaran praktik laboratorium di Prodi DIII Kebidanan Tanjungkarang belum sesuai dengan standar, sebagian besar mahasiswa kurang puas mendapatkan pelayanan pembelajaran praktik laboratorium kebidanan yang diberikan oleh dosen dan petugas laboratorium, terbukti dengan banyaknya keluhan yang dirasakan mahasiswa, seperti tempat yang tidak nyaman,peralatan yang rusak, sikap dosen dan petugas laboratorium yang kurang bersahabat, dan

3. Diperlukan langkah-langkah untuk meningkatkan mutu pembelajaran praktik laboratorium kebidanan dengan menerapkan Konsep PDCA (Plan-Do-Chek-Act), dan untuk pengembangan dimensi mutu pembelajaran praktik laboratorium kebidanan, digunakan lima dimensi pokok dalam menilai kualitas pelayanan yaitu: kehandalan (reliability), daya tanggap (responsiveness), kepastian (assurance), empati (emphaty) dan berwujud (tangibel).

\section{SARAN}

1. Dalam perencanaan pengajaran praktik laboratorium kebidanan, agar kiranya dibuat prosedur-prosedur yang jelasdalam bentukbuku panduan pelaksanaan kegiatan peraktikum yang baku, sebagai bahan rujukan dalam pelaksanaan pembelajaran praktik laboratorium,

2. Pelaksanaan pembelajaran praktik laboratorium kebidanan, hendaknya selalu dilakukan pengembangan metode pembelajaran praktik laboratorium dengan menggunakan multi mediayang relevan dengan kompetensi yang diharapkan, dan selalu berusaha meningkatkan mutu pembelajaran dengan mengutamakan kepuasan pelanggan (mahasiswa),

3. Evaluasi pembelajaran praktik laboratorium pada mahasiswa hendaknya bukan dilakukan saat Ujian Akhir Semester (UAS) saja, sebaiknya evaluasi dilaksanakan secara keseluruhan meliputi: evaluasi in-put, proses dan hasil, dan

4. Untuk menunjang pencapai mutu pembelajaran praktik laboratorium hendaknya dosen melaksanakan peningkatan mutu pembelajaran laboratorium dalam demensi: kehandalan, daya tanggap, kepastian, empati dan berwujud. 


\section{DAFTAR PUSTAKA}

Departemen Kesehatan RI. 2002. Kurikulum Nasional Pendidikan Diploma III Kebidanan. Jakarta.

Departemen Pendidikan Nasional SK Nomer 045/U/2002. 2002. Tentang Kurikulum Perguruan Tinggi.

Deming, W Edwards. 1986. Out of the Crisis, Cambridge Univesity, Cambridge.

Engkoswara. 2010. Administrasi Pendidikan. Bandung : Alfabet.

Goetsch, D.L \& Davis, S. 1994. Introduction to Total Quality, Productivity, Competitiveness. Englewood Cliffs, NJ: Prentice Hall International, Inc.

Juran,J.M. 1989. Juran on Leadership for Quality. Macmilan: New York.

Kemenkes RI. 2010. Rencana Strategis Kementerian Kesehatan 2010-2014. Jakarta: Kementerian Kesehatan RI.

Notoatmodjo. 2003. Pengantar Pendidikan Kesehatan dan Ilmu Perilaku Kesehatan. Yogyakarta.
Nursalam. 2008. Manajemen Keperawatan Aplikasi dalam Praktek Keperawatan Profesional. Edisi 2. Salemba: Medika.

Robins, Bregman, Stag, dan Coulter. 2003. Management 3rd Edition. Melbourne: Prentice Hall.

Sallis Edward. 2010. Manajemen Mutu Terpadu Pendidikan (TQM in Education) IRCiSoD: Yogyakarta.

Simamora, B. 2000. Memenangkan Pasar Dengan Pemasaran Efektif dan Profitabel. Jakarta: PT Gramedia Pustaka Utama.

Spanbaeur, Stanley J. 1987. Quality First in Education. Why Not?. Fox Valley Tecknical College Foundation, Appleton, Ninsconsin.

Tjiptono Fandy dan Diana Anastasia. 1998. Total Quality Management (TQM). Yogyakarta: Andi Offset.

Undang-Undang RI Nomor 20 Tahun 2003. 2003. Sistem Pendidikan Nasional. Bandung: Citra Umbara. 